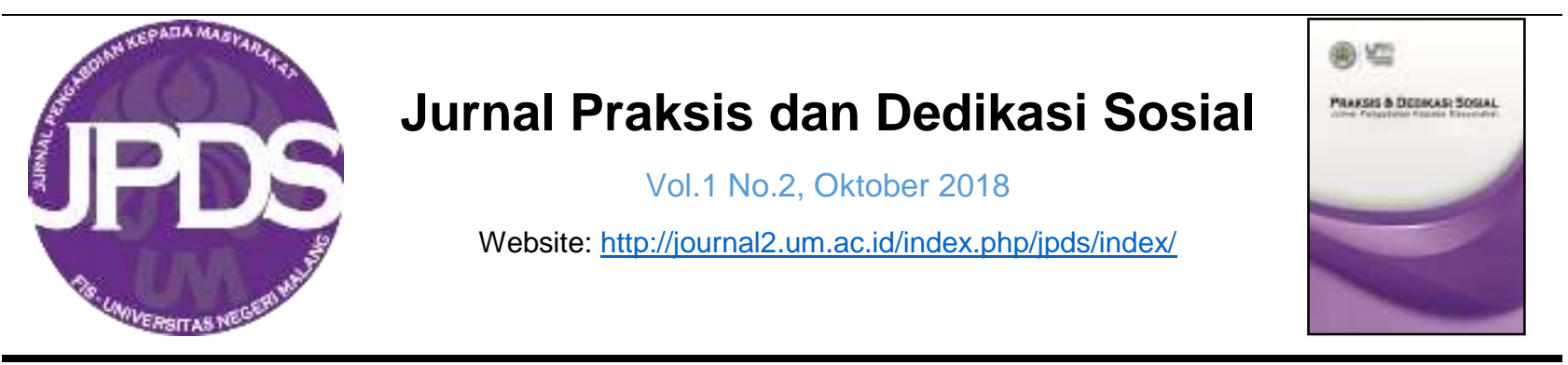

\title{
PROGRAM PEMBERDAYAAN WISATA KAMPUNG BATIK DI DESA NGABAB KABUPATEN MALANG MELALUI PENDEKATAN CIPOO
}

\author{
Najmah Zahiroh ${ }^{1}$, Susi Susanti ${ }^{2}$, Rizka Maulidia Iffani Amalia $^{3}$, Shofia Amin Maulidia $^{4}$, \\ Inayatul Maula ${ }^{5}$ \\ 1,2,3,4,5 Jurusan Sosiologi, Fakultas IImu Sosial, Universitas Negeri Malang. \\ Diterima 8 Juli 2018, dipublikasikan 31 Oktober 2018.
}

\begin{abstract}
Abstrak
Pemberdayaan masyarakat merupakan salah satu upaya mengoptimalisasi potensi yang dimiliki masyarakat. Dalam konteks pengabdian kepada masyarakat yang dijalankan, konten pemberdayaan masyarakat dilakukan di Desa Ngabab Kabupaten Malang melalui program pemberdayaan berupa Wisata Edukasi Kampung Batik. Pendekatan yang digunakan yaitu berbasis CIPOO (Context, Input, Process Output dan Outcome). Dengan memanfaatkan potensi masyarakat aktif dan kreatif maka terlaksanakanlah program pemberdayaan tersebut. Hasil analisis dari program menunjukkan bahwa masih terdapat titik-titik yang masih perlu diperbaiki. Domestifikasi peran perempuan dalam proses pemberdayaan perlu dihilangkan dengan melibatkan perempuan langsung dalam proses pengambilan keputusan serta struktur pemberdayaan. Berkaitan dengan kurangnya pendanaan cat, maka perlu diadakannya pengajuan sponsorship cat. Perlunya pendampingan rutin dalam proses pelatihan serta proses pelaksanaan pemberdayaan agar dapat berjalan dengan maksimal. Jaringan pemberdayaan sudah cukup baik karena sudah menjalin kerjasama dengan pihak eksternal. Masyarakatpun sudah cukup komunikatif serta alur kordinasi mulai tertata dengan baik.
\end{abstract}

\section{Kata Kunci}

Pemberdayaan, CIPOO, Kampung Batik

(C) 2018 Penulis

\section{PENDAHULUAN}

Pemberdayaan

masyarakat

merupakan salah satu upaya untuk memberdayakan masyarakat karena ketidakmampuannya baik dari faktor internal maupun eksternal. Pemberdayaan diharapkan mampu mengubah tatanan hidup masyarakat ke arah yang lebih baik. Pemberdayaan tidak terlepas dari

\footnotetext{
${ }^{1}$ Surel Korespondensi: najmahzahiroh45@gmail.com
}

perencanaan dalam pengelolaannya itu sendiri, kegagalan atau keberhasilan terletak pada bagaimana strategi dalam perencanaan pengelolaan. Strategi digunakan agar tujuan pemberdayaan masyarakat tersebut tercapai. Berkenaan dengan pemaknaan konsep pemberdayaan masyarakat, Ife (1995) menyatakan bahwa: "Empowerment is a process of helping disadvantaged groups and individual to compete more effectively 
Program Pemberdayaan Wisata Kampung Batik di Desa Ngabab...

with other interests, by helping them to learn and use in lobbying, using the media, engaging in political action, understanding how to 'work the system,' and so on" (Hadi, 2010). Definisi tersebut di atas mengartikan konsep pemberdayaan sebagai upaya memberikan otonomi, wewenang, dan kepercayaan kepada setiap individu dalam suatu organisasi, serta mendorong mereka untuk kreatif agar dapat menyelesaikan tugasnya sebaik mungkin.

Proses pengembangan pemberdayaan tentu memiliki serangkaian kegiatan serta hambatan. Adapun hambatan dalam pemberdayaan di pengelolaan program Desa Wisata oleh Pokdarwis Krebet Binangun yakni kurangnya kesadaran masyarakat, kurang optimalnya koordinasi masing-masing bidang, kurangnya perhatian pemerintah sarana dan prasarana kurang memadai (Desiati, 2013). Kendala dalam proses pemberdayaan juga dialami oleh pemberdayaan di Desa Wisata Panglipuran yakni arus modernisasi, sikap masyarakat, terbatasnya sumber daya manusia dan ketersediaan akomodasi wisata serta kurangnya kegiatan promosi (Andayani, Martono, \& Muhamad, 2017).

Pemberdayaan masyarakat telah dilaksanakan di Desa Ngabab Kabupaten Malang yang bertema Wisata Edukasi Kampung Batik. Mengangkat kearifan lokal Indonesia berupa batik yang berimplikasi pada terwujudnya batik khas Ngabab. Meski program pemberdayaan bertemakan batik namun didalamnya masih terdapat program kegiatan yang diselenggarakan untuk melengkapi terwujudnya Wisata Edukasi tersebut seperti keripik wortel, pelatihan membatik, taman, kebun stroberi dan kerajinan tangan. Untuk menggali kelemahan serta potensi pengembangan Wisata Edukasi kampung batik perlu diadakannya analisis pemberdayaan. Terdapat beberapa pendekatan atau metode yang dapat digunakan salah satunya yaitu pendekatan CIPOO yakni Context, Input, Process Output dan Outcome (Krisnawati, 2016). Pendekatan CIPOO digunakan dengan harapan dapat menganalisis kelemahan serta kelebihan proses pemberdayaan yang ada dengan tujuan untuk menjadi sebagai bahan perbaikan pelaksanaan program pemberdayaan.

\section{METODE}

Penelitian ini menggunakan metode kualitatif. Kualitatif adalah suatu prosedur penelitian yang menghasilkan data deskriptif berupa kata-kata baik tertulis atau lisan dan perilaku yang dapat diamati (Moleong, 2000). CIPOO digunakan sebagai alat untuk mengevaluasi pemberdayaan. Pendekatan CIPOO membahas context, input, process, output, outcome. Jenis penelitian ini menggunakan penelitian deskriptif yang pada nantinya data-data hasil penelitian dituliskan dalam bentuk kata-kata secara deskriptif. 
Najmah Zahiroh dkk.

Adapun tahapan penelitian ini yaitu pertama tahap orientasi yang dilakukan peneliti untuk mengeksplor gambaran umum lokasi penelitian berdasarkan riset terdahulu. Kemudian dilanjutkan dengan tahap kedua yaitu eksplorasi fokus yang dilakukan untuk menggali data melalui proses wawancara pada informan yang telah ditentukan. Dilanjutkan dengan pemerikasaan keabsahan data atas datadata yang diperoleh saat penggalian data. Kehadiran Peneliti. Kehadirn peneliti dalam penelitian ini sebagai pengamat partisipan. Hal ini dilakukan agar mendapat data yang alamiah atau sebenarnya tanpa dimanipulasi oleh informan.

\section{HASIL DAN PEMBAHASAN}

Desa Ngabab terdapat di Kecamatan Pujon Kabupaten Malang. Desa tersebut terletak di dataran tinggi dan berbukit, dengan ketinggian $1200 \mathrm{~m}$ di atas permukaan laut dengan kisaran suhu antara $8-18{ }^{\circ} \mathrm{C}$, curah hujan 2,3 s/d 2400 $\mathrm{mm} / \mathrm{th}$. Desa Ngabab adalah Sebuah desa kecil yang jumlah penduduknya masih cenderung sedikit yaitu sekitar 6.617 jiwa. Akses jalan menuju Desa Ngabab cenderung berkelak kelok dan menanjak. Desa Ngabab dilewati jalur utama lalu lintas darat yang menghubungkan antara Kota Kediri Dan Kota Malang. Desa Ngabab Berbatasan Langsung Dengan Desa Tulungrejo (sebelah barat), Desa Sukomulyo (sebelah selatan), Desa Tawang Sari (sebelah utara), Dan Desa Ngroto (sebelah timur). Luas wilayah Desa Ngabab adalah $1244.93 \mathrm{Ha}$ yang digunakan sebagai hutan lindung, hutan produksi, ladang, pemukiman, perkebunan, dan fasilitas umum lainnya.

Mayoritas penduduk Desa Ngabab bermata pencaharian sebagai Petani dan Beternak. Desa ini merupakan salah satu penghasil paling potensial dalam segi pertanian dan penghasil sayur terbesar di Kabupaten Malang. Sayur mayur hasil pertanian dari daerah ini antara lain adalah wortel, cabe, kacang panjang, kentang, kubis, sawi, tomat, dan lain sebagainya. Selain sayur mayur, potensi pertanian dari daerah ini adalah berupa tanaman buah-buahan (jeruk dan apel), dan tanaman palawija (jagung). Dari segi pertanian, di Desa Ngabab ini juga penghasil susu sapi terbesar yang ada di Kecamatan Pujon.

Masyarakat Desa Ngabab sangat kental dalam segi kebudayaanya. Dibuktikan dengan saat adanya acara Selametan Desa masyarakat sangat antusias dalam proses persiapan hingga pelaksanaannya. Masyarakat Desa Ngabab sangat menghargai budayanya juga selalu ingin melestarikanya terutama kecintaannya terhadap batik. Hingga Pemerintah Desa beserta masyarakat Desa Ngabab berniat mendirikan sebuah Wisata Edukasi bertema batik.

Saat ini Pemerintah Desa Ngabab juga tengah mencanangkan program pembangunan dalam sektor pariwisata 
yang bertemakan "Menuju Desa Wisata Edukatif" yang bertajuk "Kampung Batik". Selama ini masyarakat sudah terlihat berpartisipasi aktif dalam setiap program pembangunan yang telah dicanangkan oleh pemerintah desa, terutama dalam hal kebersihan dan keindahan lingkungan. saat ini program Desa Ngabab yang berupa wisata kampung batik telah berjalan.

Dengan adanya program pemberdayaan bertemakan Kampung Batik tersebut tentu memiliki beberapa program pendukung. Oleh karena itu analisis pemberdayaan dengan pendekatan CIPOO (Context, Input, Proces, Out Put, Out Come) diharapkan dapat mengevaluasi pemberdayaan Kampung Batik.

\section{Context (Konteks)}

Konteks dalam pemberdayaan adalah keseluruhan dari sistem kelembagaan dan kekuatan yang ada dalam suatu pemberdayaan. Adapun konteks dalam pemberdayaan diklasifikasikan berdasarkan 4 bentuk, yakni: 1) Aspek Kelembagaan; 2) Sistem Manajemen; 3) Aspek Organisasi; 4) Aspek penguasaan materi pemberdayaan.

\section{Aspek Kelembagaan}

Keseluruhan masyarakat desa ngabab kebupaten malang sudah cukup aktif dalam proses pemberdayaan. Namun dalam hal ini masih terdapat domestifikasi perempuan dalam stuktur dan pembagian kerja pemberdayaan. Tercermin dalam partisipasi kelembagaan hanya diikuti oleh laki-laki, pihak perempuan hanya ikut berpatisipasi untuk membuat konsumsi yang dibutuhkan ketika para masyarakat bertugas untuk mengecat kampung batik. Meskipun demikian keberlangsungan pemberdayaan tetap berjalan secara efektif. Bahkan ketika kurang bahan untuk mengecat masyarakat menunjukkan aksinya dengan menyumbangkan uang hasil kerjanya, bahkan ada yang rela untuk mencari uang untuk membangun desa dengan cara bertani. Pengelompokan kerja menjadi sub-sub kecil pada keanggotaan pemberdayaan sudah diterapkan dengan tujuan terlaksananya program pemberdayaan dengan maksimal. Dari segi pengambilan keputusan terhadap suatu permasalahan diterapkan sistem musyawarah mufakat oleh perwakilan dari tiap-tiap RT yang tergabung dalam organisasi GANTER.

\section{Sistem Manajemen}

Bentuk nyata dari sistem menejemen yang dilakukan oleh program pemberdayaan wisata kampung batik di Desa Ngabab Kabupaten Malang adalah perumusan program kerja beserta pelaksanaannya. Adapun program yang dilaksanakan yakni: 1) Stasiun wortel, diikuti oleh ibu-ibu dan bapak-bapak yang bersedia untuk mengikuti pengembangan program stasiun wortel berupa pembuatan stik wortel; 2) Taman budidaya bunga, diikuti oleh anggota GANTER yang pada nantinya bunga-bunga tersebut akan 
diperjual belikan; 3) Batik cap, diikuti oleh masyarakat umum Desa Ngabab Kabupaten Malang dengan orientasi jangka panjang berupa penjualan batik khas Ngabab; 4) Kerajinan tangan, diikuti oleh masyarakat umum Desa Ngabab Kabupaten Malang dengan tujuan sebagai aksesoris Kampung Batik; 5) Kebun stroberi, diikuti oleh masyarakat umum Desa Ngabab Kabupaten Malang.

\section{Aspek Organisasi}

Suatu program tidak dapat berjalan dengan baik dan mengalami perkembangan pesat tanpa dibarengi oleh bentuk kerjasama dengan pihak eksternal. Begitu pula dalam pemberdayaan Kampung Batik dilakukan kerjasama dengan pihak eksternal sebagai lembaga pendukung yang berkaitan dengan program pemberdayaan wisata kampung batik yakni, UB (Universitas Brawijaya), kelompok POKDARWIS (kelompok sadar wisata), Dosen pengabdian UB Fakultas Sastra, HMJ pertanian UB dan GANTER (gabungan antar RT satu). Masingmasing lembaga mempunyai tugas dan tanggung jawab dalam pewujudan Wisata Kampung Batik.

\section{Aspek Penguasaan Materi Pemberdayaan}

Untuk memperkuat keberlangsungan program kegiatan yang telah dicanangkan sebagai pendukung pewujudan wisata Kampung Batik. Penguatan tersebut berupa: 1) Pelatihan membatik; 2) Pelatihan pembuatan kerajinan tangan; 3)
Pelatihan pembuatan stik wortel; 4) Pelatihan penanaman strawberry; 5) Ikut serta dalam festival anggrek di Kota Batu.

\section{Input (Masukan)}

Input adalah adalah potensi internal dan eksternal yang dimiliki untuk keberlangsungan proses pemberdayaan. Adapun potensi yang dimiliki oleh pemberdayaan tersebut yaitu: 1) Potensi masyarakat berupa kondisi masyarakat yang aktif, kreatif dan kompak sehingga mudah untuk mengkondisikannya; 2) Dana di peroleh dari iuran masyarakat, HMJ pertanian UB dan Dosen pengabdian Fakultas Sastra UB; 3) Fasilitas yang ada yakni, mesin spinner, vacum friying, bibit stroberi diperoleh dari HMJ Pertanian UB. Peralatan membatik diperoleh dari Dosen pengabdian UB. Cat tembok diperoleh dari iuran masyarakat.

\section{Proces (Proses)}

Proses adalah seluruh kegiatan bertahap yang dilakukan dalam kegiatan perberdayaan. Proses dibagi menjadi 4 kegiatan, meliputi: pendekatan capacity building, pendekatan new public, peningkatan kinerja, dan pendekatan substansional.

Pendekatan capacity building dilakukan melalui pelatihan-pelatihan yang meliputi: 1) Pelatihan membatik yang dikhususkan untuk ibu rumah tangga, kegiatan ini dilaksanakan disela-sela kesibukan ibu dalam mengurus rumah; 2) Pelatihan pembuatan kerajinan tangan berupa lampu hias dari bahan dasar 
sampah plastik minuman mineral, lampu diletakkan di depan rumah warga kampung batik; 3) Pelatihan pembuatan stik wortel, kegiatan ini diselenggarakan oleh HIMATETA (Himpunan Mahasiswa Teknik Pertanian) UB dengan produk berupa stik wortel beraneka rasa, basecamp dari kegiatan ini berada di kampung batik dengan nama Stasiun Wortel; 4) Pelatihan penanaman bibit strawberry, kegiatan ini dibawah binaan Dosen Pengabdian Masyarakat UB warga diberi pemahaman dalam penanaman dan pemberdayaan bibit strowberry.

Pendekatan new public management (NPM), usaha yang dilakukan oleh masyarakat kampung batik dalam bidang pemasaran adalah dalam kegiatan pemasaran stik wortel yang dibina oleh dosen dari UB dengan organisasi mahasiswa HIMATETA.

$\begin{array}{ccc}\text { Peningkatan } & \text { kinerja, } & \text { untuk } \\ \text { meningkatkan } & \text { kinerja } & \text { dalam }\end{array}$
pembangunan kampung batik dilakukan: 1) Pertemuan rutin GANTER, yang diselenggarakan pada hari Senin malam Selasa setiap 2 minggu sekali hal ini dimaksudkan untuk mengevaluasi hasil kerja serta untuk bermusyawarah dalam memutuskan satu masalah; 2) Menjalin kerja sama dengan pihak luar diantaranya dengan himpunan mahasiswa teknik pertanian (HIMATETA), dosen pengabdian Fakultas Sastra UB, KKN UM 2018; 3) Pendekatan substansional, wawasan dan pengetahuan yang didapatkan oleh masyarakat kampung batik dalam hal ini adalah dalam pelatihan pengemasan stik wortel serta dalam pengembangan inovasi produk yang dapat dijadikan sebagai peluang usaha pada masa yang akan datang.

\section{Output}

Output adalah hasil akhir setelah serangkaian proses pemberdayaan dilakukan. Hasil dalam pemberdayaan ini adalah antara lain: 1) Pembangunan kampung batik sudah mencapai 45\%, sebagian besar rumah warga belum di cat dengan motif batik; 2) Produk dari stasiun wortel berupa stik wortel dengan aneka rasa sudah mencapai tahap distribusi, pemasaran produk dilakukan secara online melalui instagram dan facebook, selain itu produk ini juga dipasarkan secara offline dirumah yoghurt dworowati serta dikampus-kampus kota Malang. 3) Hasil panen dari pemberdayaan bibit strawberry dimakan sendiri oleh warga sekitar yang merawat tanaman; 4) Produk dari hasil membatik adalah baju batik khas desa ngabab berupa motif sayur yang dijadikan sebagai almamater perangkat desa.

\section{Outcome}

Outcome adalah nilai manfaat yang ditimbulkan setelah dilaksanakannya pemberdayaan. Manfaat yang didapatkan dari pembangunan kampung batik adalah sebagai berikut: 1) Menambah wawasan masyarakat dalam membatik, terutama bagi ibu rumah tangga yang memiliki waktu luang disela-sela kesibukan dalam 
mengurus rumah tangga; 2) Menambah skill, dalam hal ini masyarakat mendapatkan skill dalam pembuatan kerajinan tangan berupa lampu serta dalam pembuatan stik wortel, selain itu masyarakat juga mendapatkan wawasan dalam pemberdayaan tanaman berupa penanaman bibit strowberry dan juga bunga; 3) Meningkatkan perekonomian, dengan didirikannya kampung batik diharapkan dapat meningkatkan penghasilan masyarakat sekitar; 4) Meningkatkan solidaritas organik, dengan diselenggarakannya berbagai kegiatan pelatihan masyarakat menjadi kompak.

\section{KESIMPULAN}

Pemberdayaan

masyarakat merupakan salah satu upaya mengoptimalisasi potensi yang dimiliki masyarakat. Pemberdayaan diharapkan mampu mengubah tatanan hidup masyarakat ke arah yang lebih baik. Pemberdayaan tidak terlepas dari perencanaan dalam pengelolaannya itu sendiri, kegagalan atau keberhasilan terletak pada bagaimana strategi dalam perencanaan pengelolaan. Pengabdian kepada masyarakat yang dilakukan di Desa Ngabab Kabupaten Malang melalui program pemberdayaan berupa Wisata Edukasi Kampung Batik, menggunakan pendekatan CIPOO menghasilkan kesimpulan: 1) Context (konteks): aspek organisasi sudah diterapkan dalam pemberdayaan, sistem pengambilan keputusan berdasarkan musyawarah mufakat, masih terdapat domestifikasi peran perempuan; 2) Input (masukan): masyarakat yang aktif, kreatif dan kompak, terdapat bantuan dari pihak eksternal berupa pendanaan, pelatihan, serta pemberian alat produksi; 3) Process (proses): pelatihan proses produksi, tahap pengemasan, hingga pelatihan proses pemasaran sudah dilakukan dengan baik; 4) Output: Pembangunan kampung batik sudah mencapai 45\%, stasiun wortel sudah mencapai tahap distribusi, Produk dari hasil membatik dijadikan sebagai almamater perangkat desa; 5) Outcome: Menambah wawasan masyarakat dalam membatik, Menambah skill, Meningkatkan perekonomian, dan meningkatkan solidaritas antar masyarakat.

Namun, hasil analisis dari serangkaian kegiatan evaluasi pemberdayaan masih terdapat titik-titik yang masih perlu diperbaiki. Domestifikasi peran perempuan dalam proses pemberdayaan perlu dihilangkan dengan melibatkan perempuan langsung dalam proses pengambilan keputusan serta struktur pemberdayaan. Berkaitan dengan kurangnya pendanaan cat, maka perlu diadakannya pengajuan sponsorship cat. Perlunya pendampingan rutin dalam proses pelatihan serta proses pelaksanaan pemberdayaan agar dapat berjalan dengan maksimal. Jaringan pemberdayaan sudah cukup baik karena sudah menjalin kerjasama dengan pihak eksternal. Masyarakatpun sudah cukup 
Program Pemberdayaan Wisata Kampung Batik di Desa Ngabab...

komunikatif serta alur kordinasi mulai tertata dengan baik.

\section{DAFTAR RUJUKAN}

Andayani, A. A. I., Martono, E., \& Muhamad, M. (2017). Pemberdayaan Masyarakat Melalui Pengembangan Desa Wisata Dan Implikasinya Terhadap Ketahanan Sosial Budaya Wilayah (Studi Di Desa Wisata Penglipuran Bali). Jurnal Ketahanan Nasional, 23(1), 1-16. https://doi.org/10.22146/jkn.18006

Desiati, R. (2013). PEMBERDAYAAN MASYARAKAT MELALUI PENGELOLAAN PROGRAM DESA WISATA. DIKLUS, 17(1). Diambil dari https://journal.uny.ac.id/index.php/dikl us/article/view/2894
Hadi, A. P. (2010). KONSEP

PEMBERDAYAAN, PARTISIPASI

DAN KELEMBAGAAN DALAM PEMBANGUNAN, 14.

J. Lexy Moleong. (2000). Metodologi Penelitian Kualitatif. Bandung: PT. Remaja Rosda Karya.

Krisnawati, A. (2016). MODEL PEMBERDAYAAN MASYARAKAT MELALUI KONSEP PERTANIAN PERKOTAAN (URBAN FARMING) (Studi Pada Kelompok Tani Elok Mekar Sari Kelurahan Semolowaru Kota Surabaya). Publika, 4(4).

Diambil dari http://jurnalmahasiswa.unesa.ac.id/ind ex.php/publika/article/view/1482 